initially binds the ligand $\mathrm{Hh}$, and Smo transduces the signal. The affinity of $\mathrm{Hh}$ for Ptc does not change when Smo is also expressed, arguing against a dimeric higher-affinity receptor. The available genetic and biochemical data imply that unoccupied Ptc inactivates the Smo pro-

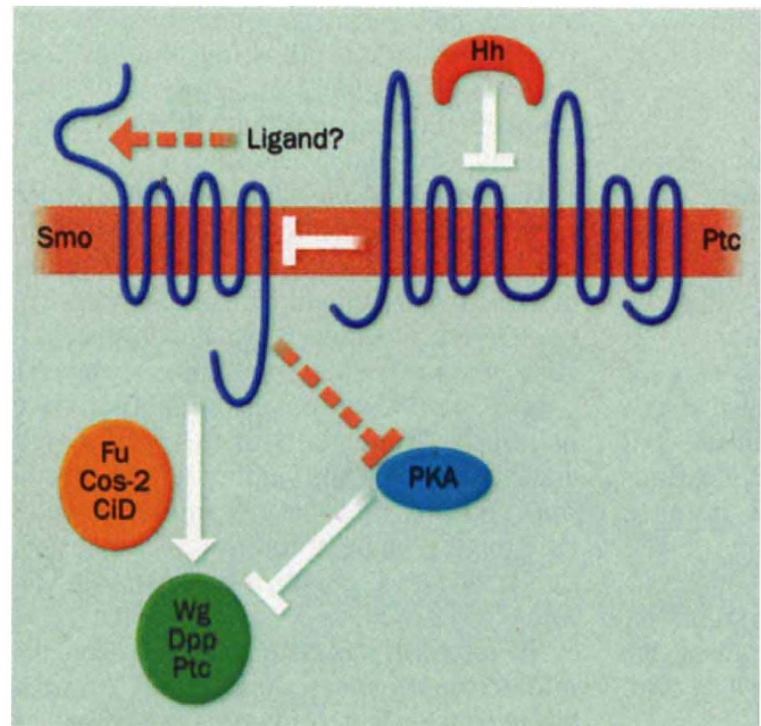

FIG. 2 Interactions between $\mathrm{Hh}$ and components of its signalling pathway, as shown by Stone et al. ${ }^{1}$ and Marigo et $a l{ }^{2}$. The secreted $\mathrm{Hh}$ protein binds to Ptc, which spans the membrane 12 times. This binding relieves the Ptc-dependent inhibition of Smo, and may involve direct contact between Smo and Ptc. Once it has been relieved from inhibitory signals, Smo activates the downstream genes $w g, d p p$ and ptc, through the signalling components Fused (Fu), Costal-2 (Cos-2) and Cubitus interruptus (CiD). This may work through the inhibition of protein kinase $A(P K A)$, although it is most likely that PKA is not regulated by $\mathrm{Hh}$ signalling, and that it acts in parallel. Dashed arrows indicate uncertain interactions, other arrows the more trusted ones.

tein, and the binding of $\mathrm{Hh}$ to Ptc relieves this inhibition, thereby activating Smo (Fig. 2). In this case, Smo would have a constitutive (that is, ligand-independent) activity in the absence of any inhibition by Ptc. But it seems equally possible that Smo has a ligand of its own, the product of a gene that has not been uncovered in genetic screens. Given the similarity between Smo and the Fz proteins, such a ligand may be a Wg-related protein, as these secreted molecules can use Fz proteins as receptors ${ }^{8}$

To test these models further, one would need to measure the downstream effects of $\mathrm{Hh}$ in cell-culture assays, in a receptordependent manner. Fortunately, there are a number of additional genes in the $\mathrm{Hh}$ pathway, some of which have measurable enzymatic functions. For example, Drosophila S2 cells (which normally express ptc) respond to the addition of $\mathrm{Hh}$ by phosphorylating Fused, which is itself a protein kinase? A better-known protein kinase in the Hh pathway is protein kinase A (PKA; reviewed in ref. 10). Inactivation of PKA has the same effect as mutations in $p t c$ - constitutive activity of the $h h$ tarcancer $^{13,14}$ get genes. In a linear pathway model, the $\mathrm{Hh}$ receptor complex would inhibit the activity of PKA, unless the receptor itself downregulated by ligand. Such a mechanism invokes cyclic AMP and a G protein, and this is an attractive candidate for a downstream effector of Smo. All too often, however, genetic interactions tend to be interpreted in a linear way, and there is good evidence that PKA acts in parallel to $\mathrm{Hh} / \mathrm{Ptc} / \mathrm{Smo}$ signalling (reviewed in ref. 10).

Finally, it is tempting to speculate how Hh interacts with its receptor. The $\mathrm{Hh}$ protein has many unusual properties, one of which is autocatalytic processing to generate a cholesterolmodified product $^{11}$. The addition of cholesterol may set constraints on the diffusion of $\mathrm{Hh}$, by tethering it to the plasma membrane. The structure of the mature protein predicts that $\mathrm{Hh}$ has an enzymatic function; it may even be proteolytic ${ }^{12}$. So Hh may work through a covalent modification of its receptor, although significant proteolytic processing of ptc is not detected ${ }^{2}$. Whatever the function of $\mathrm{Hh}$, these and other stories show that the collection of segment-polarity genes is replete with intriguing molecules and mechanisms that are important for development. And in view of the fact that human $p t c$ is a tumour-suppressor gene, they may also turn out to be important for

Roel Nusse is at the Howard Hughes Medical Institute and in the Department of Developmental Biology, Stanford University, Stanford, California 94305-5428, USA.

1. Stone, D. M. et al. Nature 384, 129-134 (1996).

2. Marigo, V., Davey, R. A., Zuo, Y., Cunningham, J. M. \& Tabin, C. J. Nature 384, 176-179 (1996).

3. Ingham. P. W. Taylor, A. M. \& Nakano, Y. Nature 353 , 184-187 (1991).

4. van den Heuvel, M. \& Ingham, P. W. Nature $\mathbf{3 8 2}$, 547-551 (1996).

547-551 (1996).

5. Alcedo, J., Ayzenzon, M., Vonohlen, T., Noll, M. \& Hooper, J. E. Cell 86, 221-232 (1996).

6. Chen, Y. \& Struhl, G. Cell 87, 553-563 (1996).

Roelink. H. et al. Cell 81, 445-455 (1995)

8. Bhanot, P. et al. Nature 382, 225-230 (1996).

9. Thérond, P. P.. Knight. J. D., Kornberg. T. B. \& Bishop, J. M. Proc. Natl Acad. Sci. USA 93, 4224-4228 (1996).

10. Blair, S. S. Nature 373, 656-657 (1995).

11. Porter, J., Young, K. \& Beachy, P. Science 274, 255-259 (1996).

12. Hall, T. M. T., Porter, J. A., Beachy, P. A. \& Leahy, D. J. Nature 378, 212-216 (1995).

13. Hahn, H. et al. Cell 85, 841-851 (1996)

14. Johnson, R. L. et al. Science 272, 1668-1671 (1996).

\section{Algal transport}

THOSE who dream of solar power always wake up to two big problems. First, you need a huge area of land to capture enough power, especially in cloudy climates. Second, you need some way of storing the energy for use at night. Daedalus now has a idea that solves both problems.

He recalls an old scheme to farm single-celled algae, notably Chlorella, which forms the green scum on stagnant ponds. Chlorella holds the record for photosynthetic efficiency, about $25 \%$, and can be processed into a nutritious but unappetizing 'flour'. Daedalus wants to use it as a fuel for water transport. A canal could easily have 10,000 square metres of surface for every kilometre of its length. Over 24 hours it would intercept an average of perhaps $1 \mathrm{MW}$ of solar power. Cover the surface with Chlorella scum, and the algae might capture and store $10 \%$ of this. A traditional canal barge was propelled on less than $1 \mathrm{~kW}$ (one horsepower, in fact). So each kilometre of the canal could power several such barges, even if their engines were not particularly efficient. Daedalus envisages some sort of rotating wire strainer ahead of the barge, to filter off the algal mat and feed it into a simple thermal engine. The waste heat from the engine could dry the incoming fuel.

In Britain and some European countries, canals were developed in the eighteenth century or earlier, when roads were sadly inadequate. In those unhygienic days, the canals often served as primitive sewage-disposal systems. Daedalus's algal canals could be used in the same way. The resulting eutrophication would recycle the waste into a thicker and more luxuriant algal scum. Furthermore, some plants are remarkably good at extracting heavy metals from solution. If Chlorella can be taught this trick too, industrial effluents could also be fed into the canals for reprocessing. Barge owners would salvage the ash from their engines to sell as metallic ore.

The other waste product from algal combustion is, of course, carbon dioxide. Chlorella grows much faster in water enriched with this gas, so it too could usefully be fed back into the canal. Daedalus freely admits that in a world awash with cheap fossil fuel and obsessed with powerful and dramatic forms of high-speed transport, his scheme is unattractive. It will come into its own in the next century, when fossil fuels have become scarce and expensive, global warming and high levels of carbon dioxide have boosted plant growth, and the rise in sea level has opened new canal routes. 